\title{
Assessing Land Loss from Flooding in the Lake St. Martin Basin in Manitoba, Canada
}

\author{
Tanzim Ahmed ${ }^{1 *}$, Raghavender Geebu ${ }^{2}$, Shirley Thompson ${ }^{2}$ \\ ${ }^{1}$ Department of Civil Engineering, University of Manitoba, Manitoba, Canada \\ ${ }^{2}$ Natural Resources Institute, University of Manitoba, Manitoba, Canada \\ Email: *ahmedt34@myumanitoba.ca,raghu.geebu@gmail.com, s.thompson@umanitoba.ca
}

How to cite this paper: Ahmed, T., Geebu, R., \& Thompson, S. (2019). Assessing Land Loss from Flooding in the Lake St. Martin Basin in Manitoba, Canada. Journal of Geoscience and Environment Protection, 7, 171-180.

https://doi.org/10.4236/gep.2019.712012

Received: October 31, 2019

Accepted: December 23, 2019

Published: December 26, 2019

Copyright $\odot 2019$ by author(s) and Scientific Research Publishing Inc. This work is licensed under the Creative Commons Attribution International License (CC BY 4.0).

http://creativecommons.org/licenses/by/4.0/

\begin{abstract}
Floodwaters from the Assiniboine River are typically diverted to Lake Manitoba and then Lake St. Martin to save the City of Winnipeg and Portage la Prairie from flooding. The four Indigenous communities living Lake St. Martin basin experienced many negative impacts, including long-term displacement after the 2011 flood. Data analysis of historical water levels of Lake Manitoba and Lake St. Martin were conducted to understand the impact of control structures and water levels. Satellite imagery allowed geographic information system (GIS) raster analysis of the shoreline change of Lake St. Martin before and after the 2011 super flood. From 1986 to 2010, the Lake St. Martin area increased slightly by approximately $0.63 \%$ but in 2011 the lake area increased by $13 \% .11,000$ acres were lost mainly around Lake St. Martin First Nation (LSMFN) reserve and the Little Saskatchewan First Nation, as a result and many houses and other buildings (churches, band offices, etc.) flooded in these communities. The shoreline change analysis showed that, in particular, the west and north shoreline of Lake St. Martin lost its beaches and lakefront properties, to become swampland after the 2011 flood. Thousands of Indigenous people were displaced for eight years, as the community could only start to rebuild its infrastructure and houses on higher ground after a government settlement was reached.
\end{abstract}

\section{Keywords}

Flood, Land Loss, Displacement, Shoreline, Indigenous, Water Diversion, Lake St. Martin

\section{Introduction}

Floods are forces of nature, which humans are powerless to stop, although floodwaters can be diverted (Thompson, 2015). Indigenous communities, all 
over the world, have been placed on marginal land to provide prime land for settlers, which makes Indigenous communities vulnerable to the impacts of flooding (Thompson, 2015). However, upstream dams and water control structures create further vulnerabilities as evident from the higher number of displaced Indigenous communities than settler communities (Ballard \& Thompson, 2013; Thompson, Ballard, \& Martin, 2014). Statistically significantly higher risk of death and injuries result for downstream communities from dams and water control structures (Zahran et al., 2008).

In 2011, floodwater from the Assiniboine River in Manitoba, Canada was flowing towards residences and infrastructure in Portage La Prairie and the City of Winnipeg, as well as farmer's fields. However, the flooding impacts were diverted north to flood Indigenous homes, churches as well as bury roads and beaches around Lake St. Martin. This water diversion resulted in the long term evacuation of entire communities, including Lake St. Martin First Nation (LSMFN), Little Saskatchewan First Nation and Dauphin River First Nation (Manitoba Infrastructure, 2018). The 2011 flood in Manitoba was nicknamed the "super flood", due to the extremely high water levels on the Assiniboine River leading to high levels in Lake Manitoba and Lake St. Martin, causing long-term negative impacts. Indigenous people were evacuated from the communities surrounding Lake St. Martin.

Many Indigenous First Nation communities living along the shoreline of Lake St. Martin, including Lake St. Martin, Little Saskatchewan, and Dauphin River First Nations, were negatively impacted. The entire community of LSMFN, an Indigenous community of 2867 people, (Indigenous and Northern Affairs Canada, 2019) was forced to evacuate their reserve within 24 hours, and remained displaced for eight years (Crabb, 2018). As well, half of both Little Saskatchewan First Nation, with a population of 1322 (Indigenous and Northern Affairs Canada, 2019) and Dauphin River, with a population of 389, (Indigenous and Northern Affairs Canada, 2019) were environmental refugees for eight years (Thompson, 2018).

After this flood of the century, several studies were conducted to reduce flood impacts stemming from the Assiniboine River system. The recommendation of these studies from the Provincial government, even after the long displacement of these Indigenous communities on Lake St. Martin, was still to divert water to Lake Manitoba and Lake St. Martin. By increasing the outflow by an emergency channel government officials reckon they can continue to channel more water to Lake St. Martin. This is despite the research showing this diversion has resulted in community members' suicides, ill-health, severe stress and marital breakdowns (Ballard et al., 2012). Although research showed the immense human suffering on Indigenous People due to the 2011 flood, no studies have determined the amount of land lost around the Lake St. Martin basin or shoreline impacts due to the government's diversion strategy. A shoreline is defined as the interface between land and water (Selvan et al., 2014). Thus, an increase in the area containing water represents a loss of land and shoreline erosion. 
The loss suffered by Indigenous communities needs to be substantiated in terms of land flooded as a result of diverting the water to Lake St. Martin. The objective of this study is to assess the impact of the 2011 flood on land loss and water levels in Lake St. Martin using satellite imagery and historical data.

\section{The Study Area}

Lake St. Martin is located in the Interlake Region between Lake Manitoba and Lake Winnipeg in Manitoba, Canada (Figure 1). The water from Lake Manitoba goes to Lake St. Martin by way of the Fairford River and then the Dauphin River, which is the only natural outlet for Lake Manitoba. The water flows from Lake Manitoba into Lake St. Martin through the Fairford River Water Control Structure (FRWCS). A film by Ballard et al. (2016) provides a visual of the flow, which the authors captured to show floodwater flow to PD in Figure 2(a), PD to Lake Manitoba in Figure 2(b), Lake Manitoba to FRWCS in Figure 2(c) and FRWCS to Lake St. Martin in Figure 2(d). FRWCS is located upstream of Lake St. Martin and downstream of Lake Manitoba.

The Portage Diversion (PD) was constructed on the Assiniboine River in 1970 to divert water from the Assiniboine River to Lake Manitoba to prevent flooding to the City of Winnipeg and Portage La Prairie (Mudry et al., 1981). Almost a decade prior to this, in 1961, to prevent the flooding of cottages, farms and communities on Lake Manitoba, FRWCS was constructed on the Fairford River to increase the outflow from the lake and to regulate Lake Manitoba in the range of $811.0 \mathrm{ft}$ to $813.0 \mathrm{ft}$ above sea level (Lake Manitoba Regulation Review Advisory Committee, 2003).

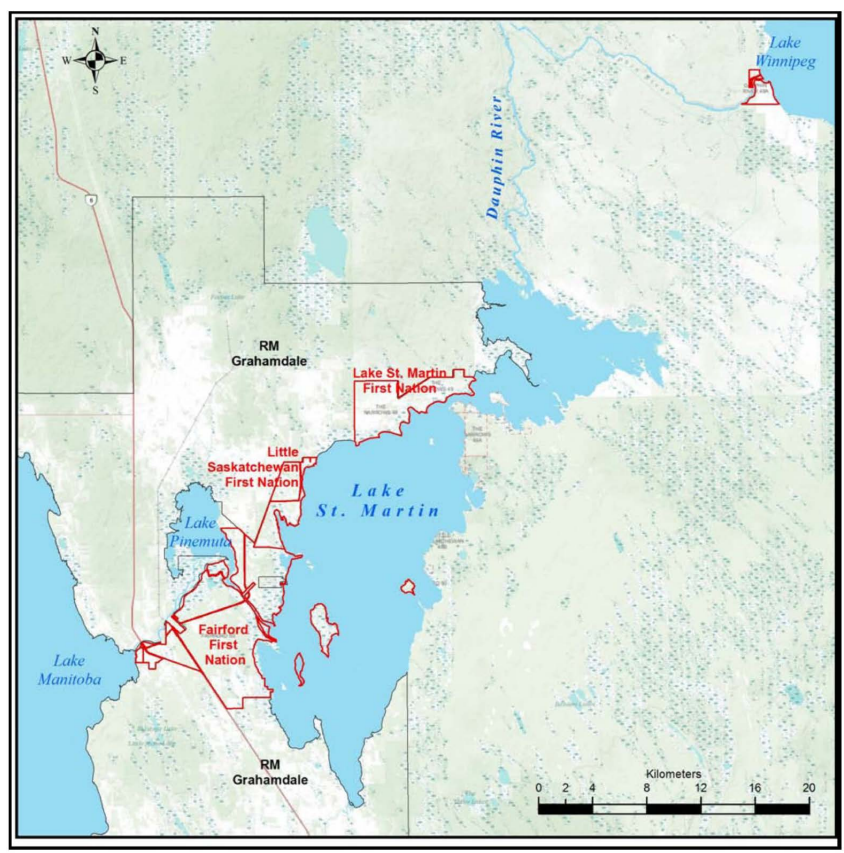

Figure 1. First Nations impacted by diversion to Lake St. Martin (Source: Government of Manitoba (2013)). 


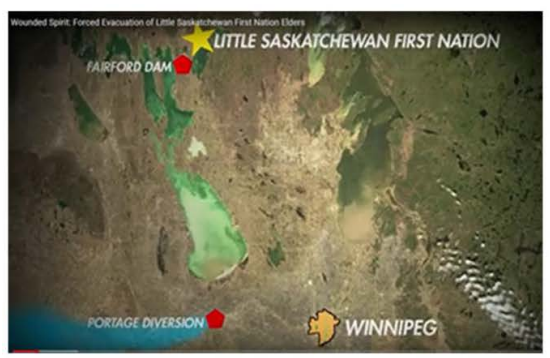

(a)

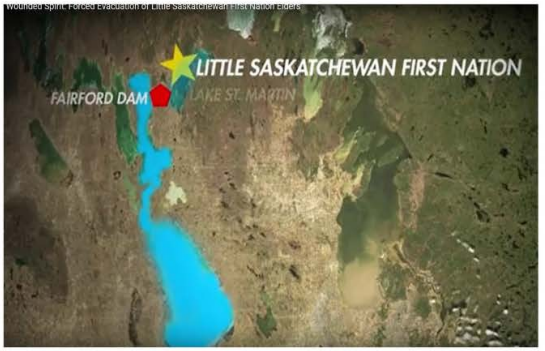

(c)

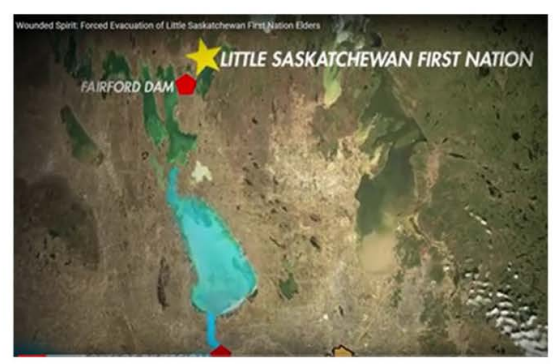

(b)

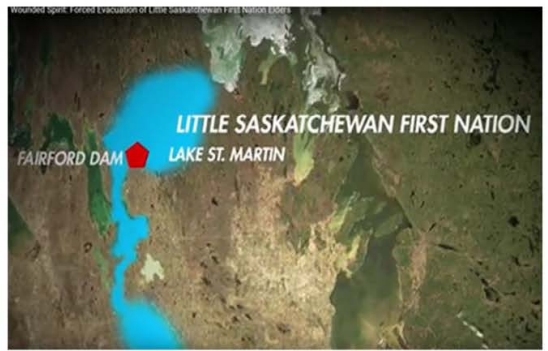

(d)

Figure 2. The water flows from Portage Diversion to Lake St. Martin when the floodway is opened (Source: Adapted from Ballard et al., (2016)). (a) Prior to Portage Diversion Opening; (b) When Portage Diversion opened and artificial floodway used in 2011; (c) The artificial flooding of Lake St. Martin and Lake Manitoba due to opening of Portage Diversion to reroute floodwaters; (d) Close up of Flooding of Lake St. Martin from Portage Diversion when the Fairford Dam control structure is opened.

\section{Method}

The water coverage in the Lake St. Martin water basin was determined over time from 1986 to 2016. Historical Landsat imagery of the full Lake St. Martin shoreline was obtained from Google Earth for the years 1986, 2010, 2011, 2012 and 2016. This Landsat imagery was preferable to aerial images collected by the provincial government, as the most recent aerial image available for this region was taken in 2011. The aerial data to 2011 was analyzed previously for only the Lake St. Martin reserve by Geebu (2017). From Landsat imagery, shape files were created using ArcGIS for the years of 1986, 2010, 2011, 2012 and 2016 of Lake St. Martin, from which the area of the lake was calculated. The authors of this study calculated the land loss using the 1986 Google Earth image as the base period.

Data analysis of historical water flows to Lake Manitoba and Lake St. Martin was conducted to understand the impact of control structures and water levels. The historical water level data for Hilbre and Steep Rock water stations and monthly flow data for FRWCS and PD from the Water Survey of Canada (WSC) were analyzed for annual flow against the average flow. The flow data for the Fairford River is available from 1955 to 2018 from the Water Survey of Canada (WSC, 2019), which includes data before the control structure on the Fairford River, FRWCS, came into operation in 1961. For the PD, this data is available from its commencement of operation in 1970 to 2015, as during the dry years from 2015 to 2018, the PD was not required to be in operation. To understand 
the impact of control structures on the Lake St. Martin area, the historical average annual flow data of these two stations were analyzed.

\section{Results and Discussion}

The historical water levels flowing to Lake Manitoba and Lake St. Martin were analyzed as well as the historical Lake St. Martin water area show similar trends over time. Regarding historical water levels, Figure 3 represents the annual flow of the Fairford River from 1955-2018. Five different periods were identified, which correlate with the operation of water control structures. The period before the operation of FRWCS (1955-1960) had the average flow of the Fairford River at 2.53 billion $\mathrm{m}^{3} / \mathrm{yr}$ but then during the FRCWS operation from 1961-1969, but prior to PD's operation, the flow decreased to 1.06 billion $\mathrm{m}^{3} / \mathrm{yr}$. When the PD began operation in 1970-2010, the PD increased the average flow at the control structure to 2.74 billion $\mathrm{m}^{3} / \mathrm{yr}$, which more than doubled the previous period from 1961 to 1969. However, during the 2011 flood, when the FRWCS operated above the regulated peak at $1.7 \mathrm{~m}$ water height, the flow reached 13.1 billion $\mathrm{m}^{3} / \mathrm{yr}$, which is more than 4.5 times the average annual flow in the period prior to 2011 from 1970 to 2010. After the 2011 "Super Flood," the average annual flow in this river between 2012 and 2018 remained high at 7.25 billion $\mathrm{m}^{3} / \mathrm{yr}$. In summary, each control structure and change in water level regulation increased the annual flow to Lake St. Martin, which maxed out during the 2011 flood and only slightly decreased between 2012-2018. Each stage seemed to create a step-wise change in flows, with the 2011 being the maximum but creating a new higher normal level that is almost four times the original flows, prior to any control structure.

Figure 4 represents the annual flow diverted from the Assiniboine River through the Portage Diversion to Lake Manitoba with outflow to Lake St. Martin. As PD started only in 1970, with no water flowing from the Assiniboine River to Lake Manitoba prior to that time there are only three distinct water levels. From 1970 to 2010, the average annual flow was 0.3 billion $\mathrm{m}^{3} / \mathrm{yr}$. During the 2011 flood, the annual flow was 5.9 billion $\mathrm{m}^{3} / \mathrm{yr}$, which was more than 19 times the average flow calculated from 1970 to 2010. Then from 2012 to 2015, the average annual flow through this diversion structure increased three times compared to the average of the period from 1970-2010.

Figure 5 shows the historical water level fluctuations of Lake Manitoba and Lake St. Martin. The figure shows that the fluctuations of Lake St. Martin are more extreme than the fluctuations observed in Lake Manitoba. Also, except during the 2011 flood, the water level of Lake Manitoba always remained between $811 \mathrm{ft}$ to $813 \mathrm{ft}$ above sea level, which was one of the main objectives of the FRWCS construction (Lake Manitoba Regulation Review Advisory Committee, 2003). During the 2011 flood, the water level at Lake Manitoba reached $814 \mathrm{ft}$, but after the 2011 flood, the lake level has been maintained within the range considered acceptable (811 - $813 \mathrm{ft})$. According to the Lake Manitoba Regulation Review Advisory Committee (2003), the level of Lake St. Martin should be 


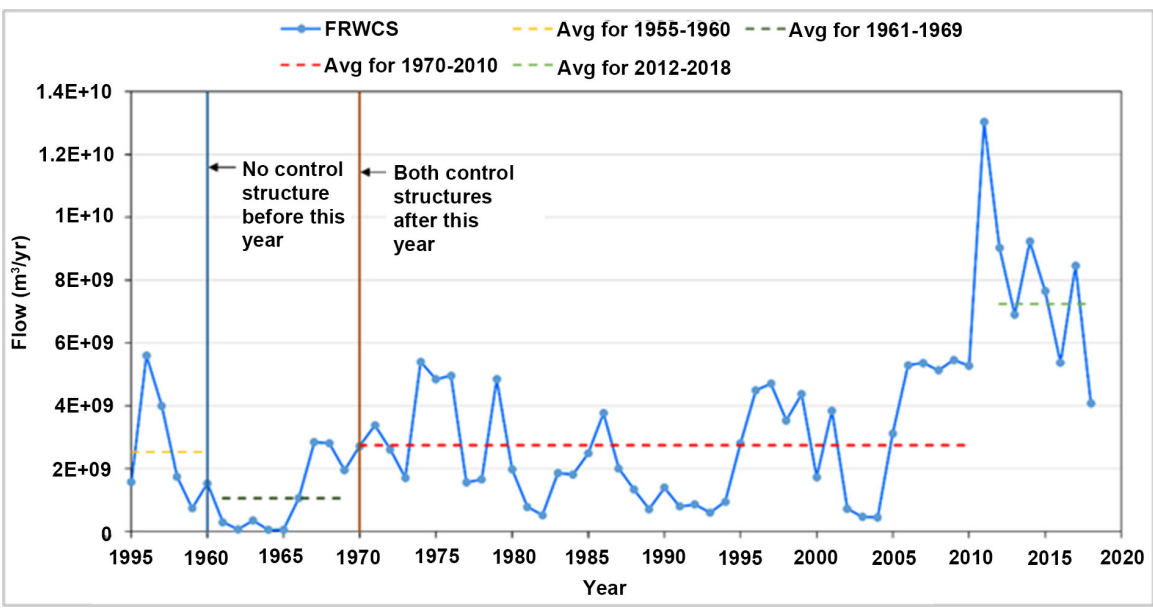

Figure 3. Mean annual flow of Fairford River before and after the Water Control Structure (1955-2018).

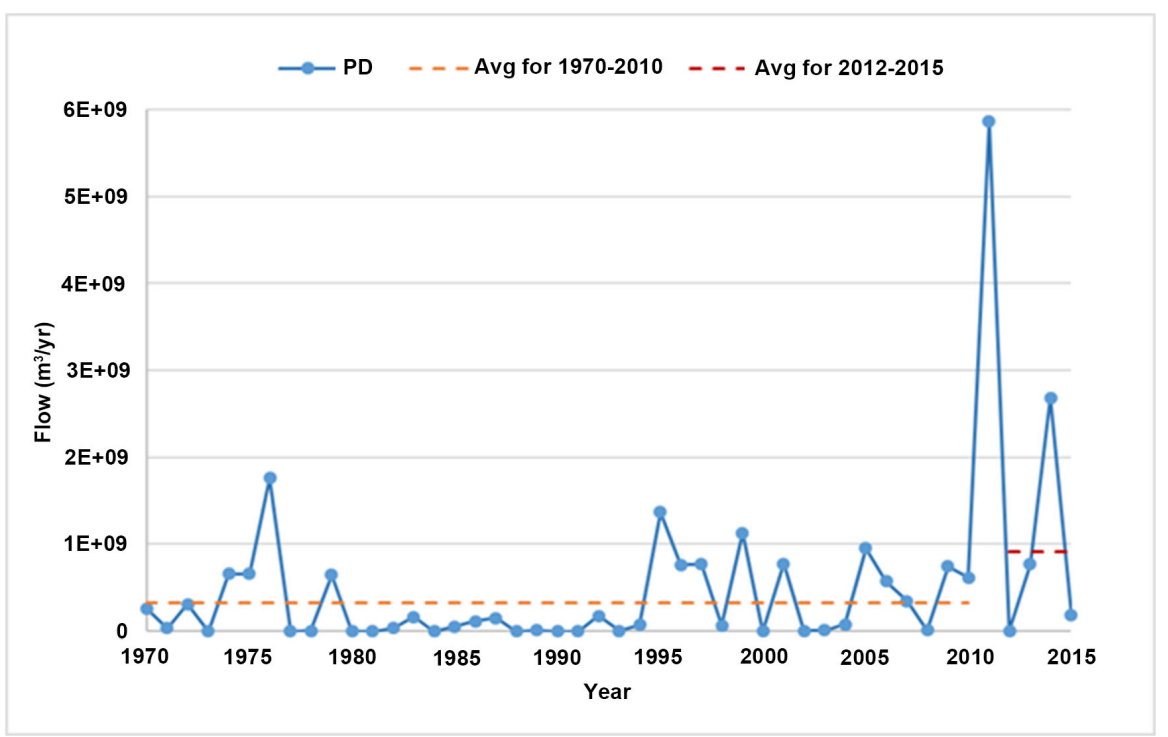

Figure 4. Mean annual flow at the Portage Diversion (1970-2015).

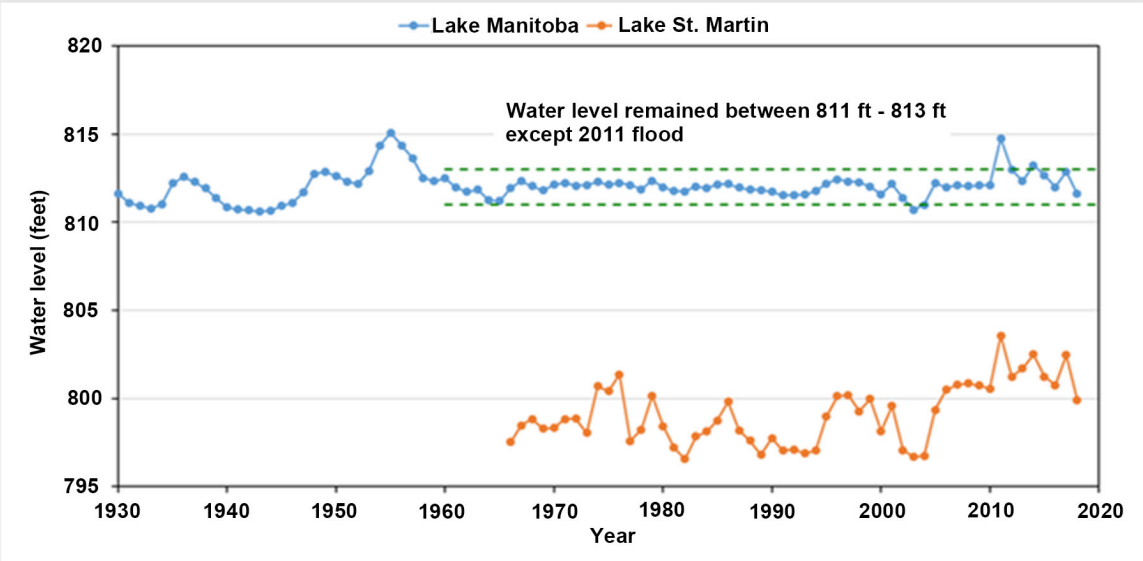

Figure 5. The mean annual water level at Lake Manitoba (Steep Rock water Station) and Lake St. Martin (Hilbre water station). 
maintained within a more natural range of $797 \mathrm{ft}$ to $800 \mathrm{ft}$, but from 2005, the lake level was observed continuously above $800 \mathrm{ft}$. This indicates that water is accumulating in Lake St. Martin.

The shoreline change in the Lake St. Martin area is visible in Figure 6 and corresponds to trends in water flow presented in Figure 5. Also, Figure 6 clearly shows that the west and north shorelines were affected by the 2011 flood more than the east and south shorelines, as documented in Thompson et al., (2014). A total of $13.2 \%$ of the land loss from flooding for the whole Lake St. Martin occurred as shown in Figure 6 and calculated by GIS, which is much higher than that calculated by Geebu (2017) for the reserve areas of 49 and 49 A. Geebu (2017) did not look at the entire lake basin but only the Lake St. Martin reserve, estimating a total loss of $6.2 \%$ only for these areas. The $13.2 \%$ in Lake St. Martin basin represents a vast amount of land that was lost.

The overflow of the lake meant housing and communities were flooded with thousands of Indigenous people displaced for eight years, particularly from LSMFN and Little Saskatchewan First Nation. In total, four different Indigenous communities suffered from both physical and mental health issues due to flooding and displacement. The stress of displacement and flooding is associated with long-term mental and physical health impacts (Thompson et al., 2014). The great majority ( 85 percent) of the LSMFN reserve has been ruled unsuitable for construction or rebuilding due to being high risk for flooding as a result of the operation of the Portage Diversion and the Fairford control structure (Thompson, 2015). Similarly, large areas of Little Saskatchewan and Dauphin River First Nations no longer can be zoned for housing or any infrastructure.

The Manitoba 2011 Flood Review Task Force reported many negative impacts from flooding (Government of Manitoba, 2013). The social and health impact of the 2011 flood included higher rates of suicide, worsening of chronic illnesses, premature mortality, increased family violence, substance abuse, post-traumatic stress disorder, depression, family breakups and recruitment of their youth by gangs in host communities (Government of Manitoba, 2013; Thompson, 2015).

Table 1 lists the calculated amount of land loss around the lake area for different years. Before the 2011 flood, the average annual flow was very low compared to the flow observed during the "Super Flood." The increased flow caused inundated homes and infrastructure on the shores of Lake St. Martin, causing

Table 1. Loss of land around Lake St. Martin from the year 1986 to 2016.

\begin{tabular}{ccccc}
\hline Year & Event & $\begin{array}{c}\text { St. Martin } \\
\text { Lake area } \\
(\mathrm{sq} \cdot \mathrm{km})\end{array}$ & $\begin{array}{c}\text { \% change in lake } \\
\text { area compared to } \\
\text { the year 1986 }\end{array}$ & $\begin{array}{c}\text { Land loss from } \\
1986(\mathrm{sq} \cdot \mathrm{km})\end{array}$ \\
\hline 1986 & Both water control structure in place & 337.62 & 0.00 & 0.00 \\
2010 & The year before the super flood & 339.76 & 0.63 & -2.14 \\
2011 & Super flood & 382.20 & 13.20 & -44.58 \\
2012 & Year after the super flood & 347.69 & 2.98 & -10.07 \\
2016 & Five years after flood & 348.07 & 3.09 & -10.44 \\
\hline
\end{tabular}




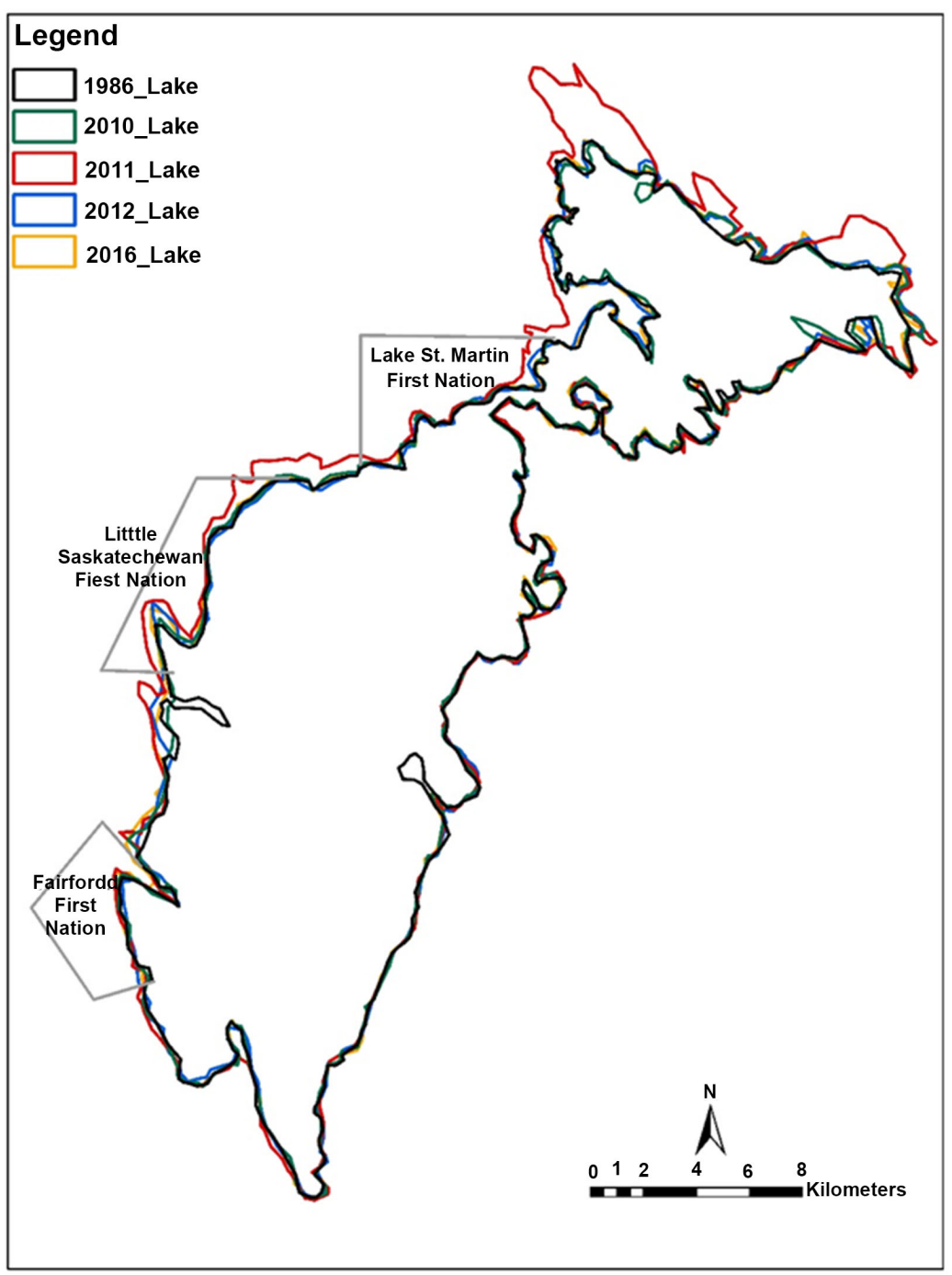

Figure 6. Land loss analysis for Lake St. Martin in Manitoba from 1986 to 2016.

more than $44 \mathrm{sq} \cdot \mathrm{km}$ land loss around this lake in the year of 2011. A few dry years followed this flood, but the floodwater remained in the water basin leaving a lot of areas uninhabitable even six years after the 2011 flood (Geebu, 2017). After the 2011 flood, the land area lost declined somewhat in 2012 and 2016 (Table 1), but remained 4.5 times greater than the years before the 2011 flood.

\section{Conclusion}

This study effectively documented the change in the land area around Lake St. Martin by analyzing satellite images with ArcGIS as well as hydrometric data. This study found that the west and north shorelines of Lake St. Martinare more prone to flooding, which corresponds with the reserve area for two First Nation communities-Lake St. Martin and Little Saskatchewan. The diversion of water from two control structures: PD and FRWCS, increased the water levels in Lake St. Martin over the years, where it accumulated. 
The comparative analysis of water level data of Lake Manitoba and Lake St. Martin showed that more rapid fluctuations in water level occur in Lake St. Martin than in Lake Manitoba. These water levels are regulated and so were determined by government policy working against Indigenous communities to protect their public infrastructure and homes. The satellite imagery analysis represents the evidence of land lost during the 2011 "Super Flood" and also that land loss has endured, remaining at $10.4 \mathrm{sq} \cdot \mathrm{km}$ in 2016, five years after the "Super Flood." The flooding shows how the water control structures and diversion paths controlled the water level in one area (Lake Manitoba) at the expense of another area (Lake St. Martin).

These water structures were built without environmental assessments or health impact assessments, inconsiderate of the damage they would wreak on Indigenous people who have a strong and ancestral connection to the land. Their displacement for eight years is linked to many mental and physical health impacts and deaths. Hence, the magnitude of the loss of land from flooding is attributed to the water structures as evidenced by increased water flows during those times of flooding. 11,000 acres were lost mainly around LSMFN reserve and the Little Saskatchewan First Nation. As a result, many houses and other buildings (churches, band offices, etc.) flooded in these communities. The shoreline change analysis showed that, in particular, the west and north shoreline of Lake St. Martin lost its beaches and lakefront properties, to become swampland after the 2011 flood. Thousands of Indigenous people were displaced for eight years, as the community could only start to rebuild its infrastructure and houses on higher ground after a government settlement were reached.

\section{Conflicts of Interest}

The authors declare no conflicts of interest regarding the publication of this paper.

\section{References}

Ballard, M., \& Thompson, S. (2013). Flooding Lake St. Martin First Nation Community: Impacts to and Future Community Plans for Sustainable Livelihoods. Canadian Journal of Nonprofit and Social Economy Research, 4, 43-65. https://doi.org/10.22230/cjnser.2013v4n1a129

Ballard, M., Klatt, R., \& Thompson, S. (2012). Flooding Hope: The Lake St. Martin First Nation Story. https://www.youtube.com/watch?v=SQStePF5jeg

Ballard, M., Klatt, R., Martin, D., \& Thompson, S. (2016). Wounded Spirit: Forced Evacuation of Little Saskatchewan First Nation Elders.

https://www.youtube.com/watch?v=PQTubc1LIjY

Crabb, J. (2018). Lake St. Martin Flood Evacuees Still Waiting to Return Home Seven Years Later.

https://winnipeg.ctvnews.ca/lake-st-martin-flood-evacuees-still-waiting-to-return-hom e-7-years-later-1.3985786

Geebu, R. (2017). Analyzing the Geographical Impact of Water Control Structures and the 2011 "Super Flood" of Manitoba on Lake St. Martin First Nation Using Historical 
Aerial Photos, Light Detection and Ranging Data, and Geographical Information System. Winnipeg: The University of Manitoba.

Government of Manitoba (2013). 2011 Flood: Technical Review of Lake Manitoba, Lake St. Martin, and Assiniboine River Water Levels.

Indigenous and Northern Affairs Canada (2019). http://fnp-ppn.aandc-aadnc.gc.ca/fnp/Main/Search/SearchFN.aspx?lang=eng

Lake Manitoba Regulation Review Advisory Committee (2003). Regulation of Water Levels on Lake Manitoba and along the Fairford River, Pinemuta Lake, Lake St. Martin and Dauphin River and Related Issues: A Report to the Manitoba Minister of Conservation.

Manitoba Infrastructure (2018). Project Description Lake Manitoba and Lake St. Martin Outlet Channels.

Mudry, N., MacKay, G. H., \& Austford, V. M. (1981). Flood Control and Flow Regulation Problems on the Assiniboine River. Canadian Water Resources Journal, 6, 157-173. https://doi.org/10.4296/cwrj0604157

Selvan, C. S., Kankara, R. S., \& Rajan, B. (2014). Assessment of Shoreline Changes along Karnataka Coast, India Using GIS \& Remote Sensing Techniques. Indian Journal of Geo-Marine Sciences, 43, 1286-1291.

Thompson, S. (2015). Flooding of First Nations and Environmental Justice in Manitoba: Case Studies of the Impacts of the 2011 Flood and Hydro Development in Manitoba. Manitoba Law Journal, 38, 220-259.

Thompson, S. (2018). Take Three: Filming Three Participatory Videos with Displaced Indigenous People from Little Saskatchewan First Nation and Lake St. Martin First Nation. International Journal of Humanities, Arts and Social Sciences, 4, 168-178. https://doi.org/10.20469/ijhss.4.10002-4

Thompson, S., Ballard, M., \& Martin, D. (2014). Environmentally and Developmentally Induced Displacement: Lake St. Martin First Nation Community Members' Experiences "We're like Refugees". Refuge, 29, 75-86.

WSC (2019). Water Survey of Canada Data. https://wateroffice.ec.gc.ca/search/historical_e.html

Zahran, S., Brody, S. D., Peacock, W. G., Vedlitz, A., \& Grover, H. (2008). Social Vulnerability and the Natural and Built Environment: A Model of Flood Casualties in Texas. Disasters, 32, 537. https://doi.org/10.1111/j.1467-7717.2008.01054.x 